\title{
Characteristics of invasion of HEp-2 cells by Providencia alcalifaciens
}

\author{
M. J. ALBERT, M. ANSARUzZAMAN, N. A. BHUIYAN, P. K. B. NEOGI and A. S. G. FARUQUe
}

International Centre for Diarrhoeal Disease Research, Bangladesh, GPO Box 128, Dhaka 1000, Bangladesh

\begin{abstract}
Summary. Previous studies with three isolates from diarrhoeal stools suggested that Providencia alcalifaciens is an invasive enteric pathogen that also causes actin condensation in infected cells. These findings were extended in the present study with a further 14 diarrhoeal stool isolates of $P$. alcalifaciens and HEp-2 cell monolayers for invasion assays. Studies on invasion characteristics with two selected isolates suggested that $P$. alcalifaciens required prior growth at $37^{\circ} \mathrm{C}$ for better invasion. Invasion and actin condensation were inhibited by an agent that inhibits microfilament formation, but not by agents that inhibit receptormediated endocytosis, microtubule formation, endosome acidification or receptor recycling. In time-course assays with HEp-2 cell monolayers maintained in medium containing gentamicin, $P$. alcalifaciens showed a small degree of multiplication after invasion of the cells, but viable bacteria could not be recovered over a 24 -h period although the integrity of the cell monolayer was preserved during this period.
\end{abstract}

\section{Introduction}

Providencia alcalifaciens is a member of the family Enterobacteriaceae and has been thought to be a cause of diarrhoea. ${ }^{1}$ Recently, three isolates of $P$. alcalifaciens (2939/90, F90-2004 and R90-1475) obtained from diarrhoeal stools were studied, and all of them were found to be invasive in the HEp-2 cell assay with an associated condensation of actin filaments. Furthermore, they produced diarrhoea in adult rabbits with removable ileal ties (RITARD model), and histological examination and electronmicroscopy showed invasion of intestinal mucosa by P. alcalifaciens. ${ }^{2,3}$ To determine the invasive ability of $P$. alcalifaciens, additional isolates from diarrhoeal stools were screened. The dynamics of intracellular multiplication of $P$. alcalifaciens in HEp-2 cells, the effects of prior growth temperature of $P$. alcalifaciens, and of some selected metabolic inhibitors on the invasion of HEp-2 cells by $P$. alcalifaciens were also studied.

\section{Materials and methods}

\section{Bacterial isolates}

Fourteen strains of $P$. alcalifaciens isolated from stools of patients with diarrhoea were studied. Strain

Received 7 April 1994; accepted 29 Aug. 1994.
F90-2004, which was one of the isolates of the previous study, was also used as a well-characterised prototype strain. ${ }^{2}$ The isolates are listed in table I along with relevant clinical details of the patients from whom they originated. Diarrhoea was classified into three categories: invasive, watery or loose. In invasive diarrhoea, there was macroscopic evidence of blood and mucus; in watery diarrhoea, the consistency was

Table I. Relevant clinical details of the patients from whom $P$. alcalifaciens was isolated

\begin{tabular}{|c|c|c|c|c|}
\hline Patient no. & Age & Sex & $\begin{array}{l}\text { Type of } \\
\text { diarrhoea }\end{array}$ & $\begin{array}{l}\text { Recognised enteric } \\
\text { pathogen isolated }\end{array}$ \\
\hline F90-2004* & Adult & $\mathbf{M}$ & Watery & $-\dagger$ \\
\hline $205 / 92$ & $12 \mathrm{y}$ & $\mathbf{M}$ & Watery & Aeromonas hydrophila \\
\hline $24496 / 92$ & $2 \mathrm{~m}$ & $\mathbf{M}$ & Invasive & Shigella boydii \\
\hline $373 / 92$ & 1 y $3 \mathrm{~m}$ & $\mathbf{M}$ & Watery & Campylobacter jejuni \\
\hline $24337 / 92$ & $2 \mathrm{~m}$ & $F$ & Loose & - \\
\hline $23672 / 92$ & $16 \mathrm{y}$ & $\mathrm{F}$ & Loose & 一 \\
\hline $24717 / 92$ & $11 \mathrm{~m}$ & $\mathbf{M}$ & Watery & 一 \\
\hline $23849 / 92$ & $3 \mathrm{~m}$ & $\mathbf{M}$ & Invasive & Shigella dysenteriae 1 \\
\hline $262 / 92$ & $5 y$ & $\mathrm{~F}$ & Watery & - \\
\hline $28390 / 92$ & $3 \mathrm{~m}$ & $\mathrm{~F}$ & NK & - \\
\hline 24331 & $2 \mathrm{~m}$ & NK & NK & - \\
\hline 10114 & 1 y $6 \mathrm{~m}$ & $\mathrm{~F}$ & Watery & Campylobacter jejuni \\
\hline 5277 & 2 y $6 \mathrm{~m}$ & $\mathrm{~F}$ & Watery & Vibrio cholerae $\mathrm{O} 139$ \\
\hline 3623 & 1 y $6 \mathrm{~m}$ & $\mathbf{M}$ & Loose & Aeromonas hydrophila \\
\hline 17867 & $45 \mathrm{y}$ & $\mathbf{M}$ & Loose & Salmonella typhi \\
\hline
\end{tabular}

NK, not known.

${ }^{*}$ This isolate was from a previous study. ${ }^{2}$

$\dagger$ No recognised pathogen isolated. 
watery; and in loose motions, the appearance was neither invasive nor watery, but sufficiently loose to assume the shape of the container. Conventional enteric pathogens, such as Salmonella, Shigella, Vibrio, Campylobacter, Aeromonas and Plesiomonas spp., parasites and rotavirus were sought in these specimens by standard methods. ${ }^{4-6}$

\section{HEp-2 cell invasion assay}

Quantitative assay. The procedure for determining HEp-2 cell invasion has been described previously. ${ }^{2}$ HEp-2 cells were seeded on glass coverslips (Bellco Glass Inc., Vineland, NJ, USA) placed in the bottom of 1-dram (3.7-ml) glass shell vials (American Scientific Products, McGraw Park, IL, USA) and grown in minimum essential medium with Earle's salts and glutamine (MEM) containing fetal bovine serum $10 \% \mathrm{v} / \mathrm{v}$ and antibiotics (Gibco, NY, USA). Before infection with the bacteria listed in table I, the growth medium was replaced with MEM lacking antibiotics; the monolayers contained $c .2 .0 \times 10^{5} \mathrm{HEp}-2$ cells. After the antibiotic-free medium was removed, the vial was inoculated with a bacterial suspension. The inocula were prepared with 4-h shaken cultures in Luria broth incubated at $37^{\circ} \mathrm{C}$, and each culture was inoculated into three vials. For this, $10 \mu \mathrm{l}$ of appropriately diluted bacterial culture mixed with $1.0 \mathrm{ml}$ of MEM (c. 1.0 $\left.\times 10^{7} \mathrm{cfu}\right)$ was inoculated into each vial. This resulted in a ratio of $c .100$ bacteria/HEp-2 cell. The bacterial inoculum was centrifuged on to the HEp- 2 cell monolayer at $800 \mathrm{~g}$ for $10 \mathrm{~min}$ and then incubated at $37^{\circ} \mathrm{C}$ in $\mathrm{CO}_{2} 5 \%$ for $2 \mathrm{~h}$. The monolayer was washed to remove non-adherent bacteria, and incubated in MEM containing gentamicin $100 \mu \mathrm{g} / \mathrm{ml}$ at $37^{\circ} \mathrm{C}$ for $1 \mathrm{~h}$ to kill extracellular bacteria. Two of the three monolayers with each bacterial inoculum were lysed with Triton X-100 1.0\% v/v for 5 min to release intracellular bacteria (this treatment did not affect the survival of bacteria). Different dilutions of the lysed monolayers were plated on MacConkey Agar (Gibco) to determine the number of $\mathrm{cfu} / \mathrm{ml}$. The other infected monolayer was fixed in methanol, stained with Giemsa stain and observed by light microscopy to examine for the integrity of the monolayer and evidence of bacterial invasion. Experiments were repeated three times for each isolate. Bacterial isolates were also exposed to gentamicin-containing MEM (without HEp-2 cells) to ensure that the isolates did not survive the antibiotic treatment. The positive control used was an invasive Shigella flexneri 2a strain, and the negative controls were Escherichia coli $\mathrm{K} 12$ and a non-pathogenic human faecal isolate of $E$. coli HS. $^{?}$

Determination of the time-course of intracellular multiplication. After a 2-h infection period with $P$. alcalifaciens isolates F90-2004 and 205/92 and the positive control strain of $S$. flexneri 2a, the tissue culture medium (MEM containing gentamicin $100 \mu \mathrm{g} / \mathrm{ml}$ ) was added to the monolayer and incubated for $1 \mathrm{~h}$ to kill extracellular bacteria, as in the invasion assay. However, instead of treating the cells with detergent after gentamicin treatment, the monolayers were washed with phosphate-buffered saline (PBS, $\mathrm{pH} 7.2$ ) and fresh medium was added. The medium contained gentamicin $10 \mu \mathrm{g} / \mathrm{ml}$ which inhibited any remaining extracellular bacteria. ${ }^{8}$ The number of $\mathrm{cfu} / \mathrm{ml}$ was determined at $0,2,4,6$ and $24 \mathrm{~h}$ after the end of the 2-h infection period after lysis of the HEp-2 cells with the detergent Triton X-100 (the zero time point was after the 2 -h infection period plus $1-\mathrm{h}$ contact period with gentamicin to kill extracellular bacteria). The medium was removed after incubation at the above mentioned time-points and fresh medium containing gentamicin $100 \mu \mathrm{g} / \mathrm{ml}$ was added for $1 \mathrm{~h}$. For time-course studies, during the long period of incubation, the concentration of antibiotic was reduced to $10 \mu \mathrm{g} / \mathrm{ml}$ to minimise the slow diffusion of the antibiotic into the intracellular compartment, and at the termination of the invasion assay at each timepoint, the concentration of antibiotic was raised again to $100 \mu \mathrm{g} / \mathrm{ml}$ to ensure the killing of extracellular bacteria. This is a standard procedure ${ }^{8,9}$ The number of bacteria at the last four time-points was compared with that at the first time-point $(0 \mathrm{~h})$ to evaluate the relative increase in numbers of intracellular bacteria. Additional infected monolayers grown on coverslips were fixed with methanol and stained with Giemsa stain after incubation for 6 and $24 \mathrm{~h}$ to evaluate the integrity of the cell monolayers. Experiments were done in duplicate and repeated at least six times. $S$. flexneri 2a, which is known to invade and multiply within the cells, was included as a control bacterium in these experiments. ${ }^{8}$

\section{Effect of temperature of growth on invasion}

The bacteria were grown as shaken cultures in Luria broth at $30^{\circ}$ and $37^{\circ} \mathrm{C}$ for $4 \mathrm{~h}$, and then quantitative invasion assays were performed at $37^{\circ} \mathrm{C}$. The experiments were performed three times in duplicate.

\section{Effect of metabolic inhibitors on invasion}

The effects on the invasion of bacteria listed in table IV of inhibitors of microfilament structure (cytochalasin D $2.5 \mu \mathrm{g} / \mathrm{ml}$ ), endosome acidification (50 $\mathrm{mm}$ ammonium chloride), receptor recycling (chloroquine $200 \mu \mathrm{g} / \mathrm{ml}$ ), receptor-mediated endocytosis (500 $\mu \mathrm{m}$ dansylcadaverine) and microtubule formation (colchicine $5 \mu \mathrm{g} / \mathrm{ml}$ ) in eukaryotes, were studied in the quantitative HEp-2 cell invasion assay. (All these reagents except ammonium chloride were obtained from Sigma, St. Louis, MO, USA; ammonium chloride was obtained from J. T. Baker Co., NJ, USA.) The cell monolayers were pre-incubated with these agents for at least $45 \mathrm{~min}$ before challenge with bacteria. Inhibitors were also present in the tissueculture medium throughout the period of the invasion assay. The effect of the concentrations of metabolic 
Table II. Invasion of HEp-2 cells by $P$. alcalifaciens and control bacteria

\begin{tabular}{|c|c|c|c|c|}
\hline \multirow{2}{*}{ Strain } & \multicolumn{2}{|c|}{ Bacteria (cfu) $/ \mathrm{ml}$} & \multirow{2}{*}{$\begin{array}{l}\text { Percentage of } \\
\text { intracellular } \\
\text { bacteria } \\
\text { relative to } \\
\text { inoculum }\end{array}$} & \multirow{2}{*}{$\begin{array}{l}\text { Fluorescent } \\
\text { actin } \\
\text { staining } \\
\text { test }\end{array}$} \\
\hline & Inoculum & Intracellular* & & \\
\hline \multicolumn{5}{|l|}{ P. alcalifaciens } \\
\hline F90-2004 & $3.6 \times 10^{7}$ & $1.0 \times 10^{4}$ & 0.03 & + \\
\hline $205 / 92$ & $9.6 \times 10^{6}$ & $1.4 \times 10^{4}$ & $0 \cdot 15$ & + \\
\hline $24496 / 92$ & $1.3 \times 10^{7}$ & $7.0 \times 10^{3}$ & 0.05 & + \\
\hline $373 / 92$ & $2.6 \times 10^{7}$ & $1.2 \times 10^{3}$ & 0.005 & + \\
\hline $24337 / 92$ & $1.2 \times 10^{7}$ & $2.8 \times 10^{4}$ & 0.23 & + \\
\hline $23672 / 92$ & $3.1 \times 10^{7}$ & $5.7 \times 10^{4}$ & $0 \cdot 18$ & + \\
\hline $24717 / 92$ & $1.6 \times 10^{7}$ & $2.7 \times 10^{4}$ & 0.17 & + \\
\hline $23849 / 92$ & $1.5 \times 10^{7}$ & $5.0 \times 10^{3}$ & 0.03 & + \\
\hline $262 / 92$ & $3.3 \times 10^{7}$ & $5.0 \times 10^{3}$ & 0.02 & + \\
\hline $28390 / 92$ & $3.5 \times 10^{7}$ & $2.3 \times 10^{4}$ & 0.07 & + \\
\hline $24331 / 91$ & $2.5 \times 10^{7}$ & $1.5 \times 10^{4}$ & 0.06 & + \\
\hline 10114 & $1 \cdot 2 \times 10^{7}$ & $1.7 \times 10^{4}$ & $0 \cdot 14$ & + \\
\hline 5277 & $1.1 \times 10^{7}$ & $4.0 \times 10^{2}$ & 0.004 & + \\
\hline 3623 & $1.5 \times 10^{7}$ & $4.0 \times 10^{3}$ & 0.03 & + \\
\hline 17867 & $1.0 \times 10^{7}$ & $6.6 \times 10^{2}$ & 0.007 & + \\
\hline S. flexneri $2 \mathrm{a}$ & $1.7 \times 10^{7}$ & $5.0 \times 10^{5}$ & $2 \cdot 9$ & + \\
\hline E. coli $\mathrm{K} 12$ & $1 \cdot 1 \times 10^{7}$ & $1.5 \times 10^{1}$ & 0.0001 & - \\
\hline E. coli $\mathrm{HS}$ & $2 \cdot 0 \times 10^{7}$ & $1.6 \times 10^{1}$ & 0.000 & - \\
\hline
\end{tabular}

*Values are averages of duplicate samples and represent data from one of three experiments.

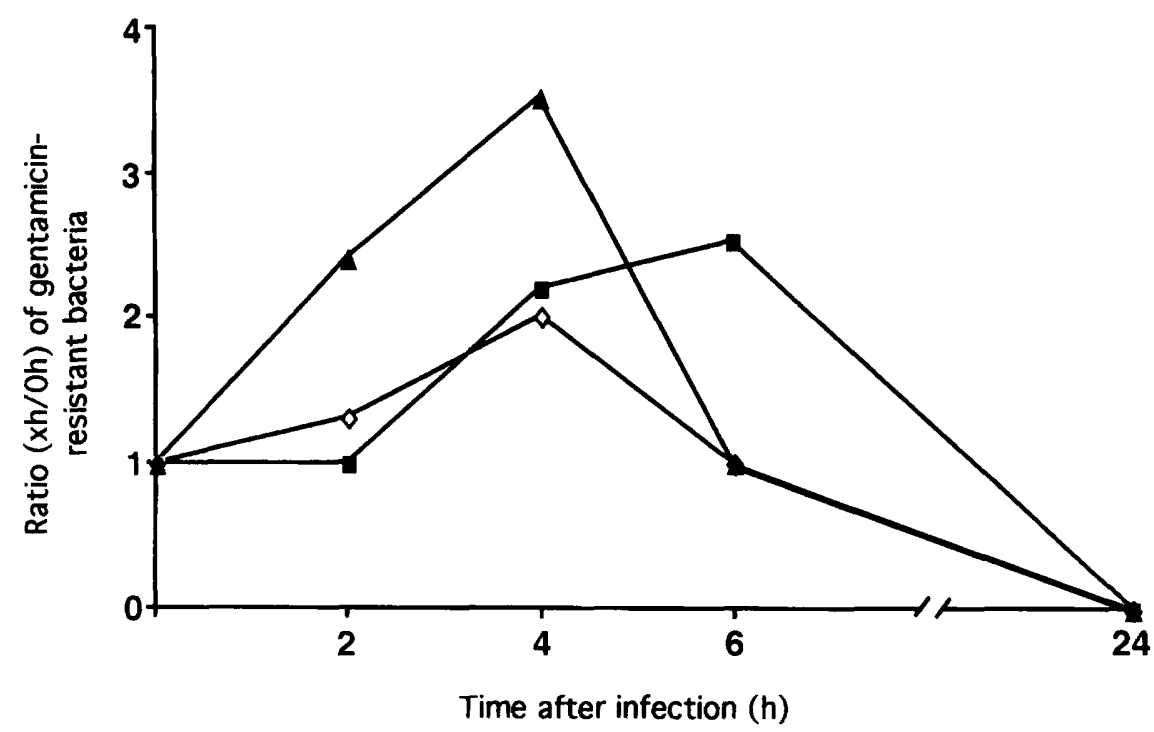

Figure. Intracellular multiplication of $P$. alcalifaciens isolates F90-2004 ( $\boldsymbol{(})$ and 205/92 ( $\diamond)$, and $S$. flexneri 2 a $(\boldsymbol{\Delta})$ in $\mathrm{HEp}-2$ cell monolayers. Values represent the ratios of gentamicin-resistant bacteria at $(\mathrm{xh} / 0 \mathrm{~h})$, and are means of duplicate assays from one of six experiments.

inhibitors used on the viability of HEp-2 cells was assessed by trypan blue exclusion staining of cells. The inhibitors were also incubated separately with bacteria for the length of the invasion assay to observe their effect on bacterial growth. The experiments were performed three times in duplicate.

\section{Fluorescent actin staining $(F A S)$ test}

The bacterial isolates listed in table II were tested for actin condensation with HEp- 2 cell monolayers in a 3-h assay as described previously. ${ }^{2}$ When testing the effect of metabolic inhibitors on actin condensation by the bacteria listed in table IV, the inhibitors were present in the tissue-culture medium as described above. The degree of actin condensation (number of fluorescent spots-one fluorescent spot was defined as contributed by a cluster of five or more bacteria) was graded on a 0 to $4+$ scale by examining 100 cells in random fields, with $4+$ assigned to actin condensation when the assay was performed without inhibitor. The experiments were performed three times in duplicate.

\section{Results}

\section{Quantitative invasion}

The results of the invasion assay with the isolates are shown in table II. All the clinical isolates, including the previously studied isolate F90-2004, were invasive and 
Table III. Effect of growth temperature of bacteria on HEp-2 cell invasion by $P$. alcalifaciens and control bacteria

\begin{tabular}{|c|c|c|c|c|c|c|}
\hline \multirow{3}{*}{ Strain } & \multicolumn{3}{|c|}{ Bacterial inoculum grown at $37^{\circ} \mathrm{C}$} & \multicolumn{3}{|c|}{ Bacterial inoculum grown at $30^{\circ} \mathrm{C}$} \\
\hline & \multicolumn{2}{|c|}{ Bacteria $(\mathrm{cfu}) / \mathrm{ml}$} & \multirow{2}{*}{$\begin{array}{l}\text { Percentage of } \\
\text { intracellular } \\
\text { bacteria } \\
\text { relative to } \\
\text { inoculum }\end{array}$} & \multicolumn{2}{|c|}{ Bacteria $(\mathrm{cfu}) / \mathrm{ml}$} & \multirow{2}{*}{$\begin{array}{c}\text { Percentage o } \\
\text { intracellular } \\
\text { bacteria } \\
\text { relative to } \\
\text { inoculum }\end{array}$} \\
\hline & Inoculum & Intracellular* & & Inoculum & Intracellular* & \\
\hline \multicolumn{7}{|l|}{ P. alcalifaciens } \\
\hline F90-2004 & $2.0 \times 10^{7}$ & $1.7 \times 10^{4}$ & 0.085 & $3.0 \times 10^{7}$ & $2.3 \times 10^{2}$ & 0.0008 \\
\hline $205 / 92$ & $1.5 \times 10^{7}$ & $3 \cdot 0 \times 10^{4}$ & $0 \cdot 2$ & $1.5 \times 10^{7}$ & $6.0 \times 10^{3}$ & 0.04 \\
\hline S. flexneri $2 \mathrm{a}$ & $4.0 \times 10^{7}$ & $1.3 \times 10^{6}$ & $3 \cdot 25$ & $1.0 \times 10^{7}$ & $5.0 \times 10^{4}$ & 0.5 \\
\hline
\end{tabular}

*Values are averages of duplicate samples and represent data from one of three experiments.

Table IV. Effects of various metabolic inhibitors on invasion of, and actin condensation in, HEp- 2 cells, by $P$. alcalifaciens and the control bacterium, $S$. flexneri $2 \mathrm{a}$

\begin{tabular}{|c|c|c|c|}
\hline \multirow[t]{2}{*}{ Inhibitor } & \multicolumn{2}{|c|}{$\begin{array}{c}\text { Invasion* (and } \\
\text { actin condensation } \dagger \text { ) by } \\
P . \text { alcalifaciens } \text { isolates }\end{array}$} & \multirow{2}{*}{$\begin{array}{c}\text { Invasion* } \\
\text { (and actin } \\
\text { condensation }{ }^{\dagger} \text { ) } \\
\text { by } S \text {. flexneri } 2 \mathrm{a}\end{array}$} \\
\hline & F90-2004 & $205 / 92$ & \\
\hline None & $100(4+)$ & $100(4+)$ & $100(4+)$ \\
\hline $\begin{array}{l}\text { Chloroquine } \\
(200 \mu \mathrm{g} / \mathrm{ml})\end{array}$ & $85(3+)$ & $90(4+)$ & $89(4+)$ \\
\hline $\begin{array}{l}\text { Ammonium chloride } \\
(50 \mathrm{~mm})\end{array}$ & $90(4+)$ & $97(4+)$ & $102(4+)$ \\
\hline $\begin{array}{l}\text { Dansylcadaverine } \\
(500 \mu \mathrm{M} / \mathrm{ml})\end{array}$ & $90(4+)$ & $85(4+)$ & $95(4+)$ \\
\hline $\begin{array}{l}\text { Cytochalasin D } \\
(2.5 \mu \mathrm{g} / \mathrm{ml})\end{array}$ & $0(0)$ & $0(0)$ & $0(0)$ \\
\hline $\begin{array}{l}\text { Colchicine } \\
(5 \mu \mathrm{g} / \mathrm{ml})\end{array}$ & $133(4+)$ & $100(4+)$ & $108(4+)$ \\
\hline
\end{tabular}

*Values represent the ratio of gentamicin-resistant bacteria in the presence of inhibitor to gentamicin-resistant bacteria without inhibitor and are expressed as percentages.

$\dagger$ Determined by fluorescent actin staining (FAS) test. The number of fluorescent spots (one fluorescent spot was defined as contributed by a cluster of five or more bacteria) in infected HEp- 2 cells without inhibitor was assigned a value of $4+$ by examining 100 cells in random fields. When the FAS test was performed with inhibitor, the number of fluorescent spots was determined on a $0-4+$ scale.

all of them also gave positive results in the test for actin condensation. The control bacteria behaved as expected: $S$. flexneri 2a was highly invasive and the negative control strains of $E$. coli exhibited weak invasion. Giemsa-stained HEp-2 cell monolayers infected with $P$. alcalifaciens and $S$. flexneri 2 a showed intracellular bacteria (data not shown).

\section{Time-course of intracellular multiplication}

The well characterised strain of $P$. alcalifaciens F902004 and a further strain shown in table II (205/92) were studied in this assay. S. flexneri 2 a was included as a positive control. The results of a typical experiment are shown in the figure. For $P$. alcalifaciens isolates, there was a slight increase in the intracellular count between the 2- and 6-h time-points, and after incubation for $24 \mathrm{~h}$ no viable bacteria were recovered. For $S$. flexneri 2a, there was rapid intracellular multiplication in the initial few hours, and at the end of $24 \mathrm{~h}$, no viable bacteria were recovered. Giemsastained cells at the end of the 24-h incubation period showed that the $P$. alcalifaciens-infected monolayer was more or less intact with some intracellular bacteria, whereas the $S$. flexneri 2a-infected monolayer was destroyed.

\section{Effect of temperature of growth on invasion}

The effect of growth temperature on invasion is shown in table III. Like the control S. flexneri 2a strains, $P$. alcalifaciens isolates exhibited higher levels of invasion when grown at $37^{\circ} \mathrm{C}$, and there was a marked reduction in invasion when grown at $30^{\circ} \mathrm{C}$.

\section{Effect of metabolic inhibitors on invasion}

The effects of metabolic inhibitors on the ability of the organisms to invade are shown in table IV. The control $S$. flexneri $2 \mathrm{a}$ isolate and both the $P$. alcalifaciens isolates behaved in a similar fashion in these assays. Cytochalasin D, an inhibitor of microfilament structure, inhibited invasion as well as actin condensation. The other agents, chloroquine (inhibitor of receptor recycling), ammonium chloride (inhibitor of endosome acidification), dansylcadaverine (inhibitor of receptor-mediated endocytosis) and colchicine (inhibitor of microtubule formation) did not seem to have any appreciable effect on invasion or actin condensation by the isolates. These agents, including cytochalasin D, did not have any inhibitory effect on bacterial growth and also did not affect the viability of HEp-2 cells (data not shown).

\section{Discussion}

In a previous study three diarrhoeal stool isolates of $P$. alcalifaciens were found to be invasive. ${ }^{2}$ This observation was extended with an additional 14 
isolates from diarrhoeal stools in the present study. This suggests that invasiveness is a property commonly found among P. alcalifaciens isolates. All these isolates also caused polymerisation of actin filaments as shown by the FAS test. In six of the 14 diarrhoeal patients from whom the isolates originated, $P$. alcalifaciens was the only putative pathogen present, and in others it was mixed with recognised enteric pathogens. Of the 14 diarrhoeal patients, the type of diarrhoea in two was not known, two patients from whom Shigella spp. were isolated had invasive diarrhoea and the remaining 10 had either watery diarrhoea or loose stool. It is not unusual to find some patients infected with invasive pathogens like Salmonella spp. and $S$. sonnei presenting with watery diarrhoea. ${ }^{10,11}$ Although $P$. alcalifaciens possesses invasive characteristics, it may not be overly invasive and produces either loose or watery diarrhoea most of the time. Additional evidence for the role of $P$. alcalifaciens in the causation of diarrhoea should come from case-control studies.

The kinetics of invasion of, and intracellular survival in, HEp-2 cells suggested that, after invasion, $P$. alcalifaciens isolates showed some degree of multiplication and were killed over a 24-h period. After incubation for $24 \mathrm{~h}$, Giemsa-staining showed that the majority of HEp-2 cells were intact with some intracellular bacteria, and the intracellular bacteria were obviously dead. The lack of appreciable damage to
HEp-2 cell monolayers may also indicate the mild nature of invasion by $P$. alcalifaciens. In contrast, $S$. flexneri multiplied rapidly initially, lysed the cells, escaped and was killed by exposure to the antibiotic. ${ }^{8}$ Giemsa-stained S. flexneri-infected cells incubated for $24 \mathrm{~h}$ showed that the monolayer was destroyed, as expected.

For optimal expression of the invasive phenotype, the $P$. alcalifaciens isolates required prior growth at $37^{\circ} \mathrm{C}$. By analogy with a person-to-person transmitted pathogen, $S$. flexneri, which also requires prior growth at $37^{\circ} \mathrm{C}$ for optimal invasion of cells, ${ }^{8,12}$ our finding suggests that the mode of transmission of $P$. alcalifaciens might be like that of Shigella spp.

Studies on the effect of metabolic inhibitors on invasion suggested that, like all invasive pathogens including Shigella spp., invasion by $P$. alcalifaciens was inhibited by the microfilament inhibitor, cytochalasin $\mathrm{D}$, but not by any of the other inhibitors studied. ${ }^{8,9,13}$ The actin condensation data also corroborated these findings. In-vitro invasion studies with polarised intestinal epithelial cell monolayers ${ }^{14}$ and intestinal mucosal biopsy studies of patients suffering from $P$. alcalifaciens diarrhoea should shed more light on the invasive characteristics of $P$. alcalifaciens.

This research was supported by the International Centre for Diarrhoeal Disease Research, Bangladesh (ICDDR, B). We thank $\mathrm{Mr}$ M. Haque for secretarial assistance.

\section{References}

1. Haynes J, Hawkey PM. Providencia alcalifaciens and travellers' diarrhoea. BMJ 1989; 299: 94-95.

2. Albert MJ, Alam K, Ansaruzzaman $\mathbf{M}$ et al. Pathogenesis of Providencia alcalifaciens-induced diarrhoea. Infect Immun 1992; 60: 5017-5024.

3. Mathan M, Mathan VI, Albert MJ. Electron microscopic study of the attachment and penetration of rabbit intestinal epithelium by Providencia alcalifaciens. J Pathol 1993; 171: 67-71.

4. Rahim Z, Kay BA. Enrichment for Plesiomonas shigelloides from stools. J Clin Microbiol 1988; 26: 789-790.

5. Shimada T, Nair GB, Deb BC, Albert MJ, Sack RB, Takeda Y. Outbreak of Vibrio cholerae non-O1 in India and Bangladesh. Lancet 1993; 341 : 1347.

6. WHO. Programme for control of diarrhoeal diseases (CDD/83.3). Manual for laboratory investigations of acute enteric infections. Geneva, World Health Organization1987: 9-20.

7. Robins-Browne RM, Bennett-Wood V. Quantitative assessment of the ability of Escherichia coli to invade cultured animal cells. Microb Pathog 1992; 12: 159-164.

8. Finlay BB, Falkow S. Comparison of the invasion strategies used by Salmonella cholerae-suis, Shigella flexneri and Yersinia enterocolitica to enter cultured animal cells: endosome acidification is not required for bacterial invasion or intracellular replication. Biochimie 1988; 70: 1089-1099.

9. Konkel ME, Hayes SF, Lynn LA, Cieplak W. Characteristics of the internalization and intracellular survival of Campylobacter jejuni in human epithelial cell cultures. Microb Pathog 1992; 13: 357-370.

10. Butler T. Salmonellosis. In: Warren KS, Mahmoud AF (eds) Tropical and geographical medicine, 2nd edn. New York, McGraw-Hill Book Co. 1990: 757-772.

11. Stool BJ, Glass RI, Huq MI, Khan MU, Banu H, Holt J. Epidemiologic and clinical features of patients infected with Shigella who attended a diarrheal disease hospital in Bangladesh. J Infect Dis 1982; 146: 177-183.

12. Small PLC, Isberg RR, Falkow S. Comparison of the ability of enteroinvasive Escherichia coli, Salmonella typhimurium, Yersinia pseudotuberculosis, and Yersinia enterocolitica to enter and replicate within HEp-2 cells. Infect Immun 1987; 55: 1674-1679.

13. Janda JM, Abbott SL, Oshiro LS. Penetration and replication of Edwardsiella spp. in HEp-2 cells. Infect Immun 1991 ; 59 : 154-161.

14. Everest PH, Goossens H, Butzler J-P et al. Differentiated Caco2 cells as a model for enteric invasion by Campylobacter jejuni and C. coli. J Med Microbiol 1992; 37: 319-325. 